\title{
Morphological and Nutritive Variation in a Collection of Cucurbita pepo L. Growing in Kosova
}

\author{
Sali ALIU ${ }^{1}$, Arben HAZIRI ${ }^{2}$, Shukri FETAHU ${ }^{1}$, Nevzat ALIAGA ${ }^{2}$ \\ Imer RUSINOVCI ${ }^{1}$, Imer HAZIRI' ${ }^{1}$, Valentina ARAPI ${ }^{3}$ \\ ${ }^{1}$ University of Prishtina, Faculty of Agriculture, Department of Crop Science, 10000, Prishtina, Kosova; salialiu02@gmail.com \\ ${ }^{2}$ University of Prishtina, Faculty of Natural Science, Department of Chemistry, 10000, Prishtina, Kosova \\ ${ }^{3}$ Agriculture University of Tirana, Department of food technology, Tirana, Albania
}

\begin{abstract}
Kosovo is the one of the important diversity centers for Cucurbita pepo because of their adaptation to diverse agro ecological conditions as a result of natural and also farmer's selection. In Kosovo, in most cases C. pepo is grown both in maize fields and vegetable gardens as well as in other more intensive systems. Our expedition have identified different location in the part of Kosovo where were collected a samples at altitudes from 545 till 748 MASL. Kjeldahl method we have used to determine Protein content (PC). Lipids were determined by extraction using Soxhlet apparatus and diethyl ether was used as extraction solvent. The aim of the present investigation was carried out to study morphological diversity, protein and lipids content. Pumpkin populations show great diversity in morphological characteristics, particularly fruit weight $(\mathrm{FW})$, fruit shape $(\mathrm{FSH})$. All populations for FW were on higher genetic variability +2556.9 g or $97.71 \%$. The collection showed appreciable phenotypic variation in fruit shape (FSH). The greater part of variance was accounted for protein content (PC) and lipids content (LC). The estimation overall value $\mu$ in seed for PC and LC were 14.59\%, and 32.99\% respectively. This evaluation of traits variability can assist breeders to identify populations with desirable characteristics for inclusion in variety breeding programs.
\end{abstract}

Keywords: diversity, lipid content, morphological characterization, pumpkin, protein content

\section{Introduction}

According to archaeological recordings, C. реро appears to be one of the first domesticated species. The oldest remains have been found in Mexico, in the Oaxaca valley (8750 BC to AD 700) and in the caves of Ocampo, Tamaulipas (7000 to $500 \mathrm{BC}$ ). Its presence in the United States also dates back a long time, as the recordings in Missouri (4000 BC) and Mississippi (1400 BC) indicate. This species may have been domesticated at least on two occasions and in two different regions: in Mexico and in the eastern United States, in each case having $C$. fraterna and C. texana, respectively, as possible progenitors. (Hernándo Bermejo and León, 1994), but was introduced to Europe only about 500 years ago (Whitaker, 1947). One plant group with the most species used as human food is the $\mathrm{Cu}$ curbitaceae family. Within this family, the genus Cucurbita stands out as one of the most important. The Cucurbitaceae family consists of 90 genera and approximately 700 species (Francois et al., 2006). Cucurbits (Cucurbitaceae) are among the most important plant families supplying with edible products and useful fibers (Bisognin, 2002). Kosovo is the one of the important diversity centers for $C$. pepo because of their adaptation to diverse agro ecological conditions as a result of natural and also farmer's selection. In Kosovo, in most cases $C$. pepo is grown both in maize fields and vegetable gardens as well as in other more intensive systems. Like the other cultivated species of the genus, the mature or young fruit and the seeds of $C$. pepo, as well as to a lesser extent the flowers and young tips of the stems are eaten in many parts of its native distribution area and in other regions of the world. C. pepo's nutrient content is similar to that described for the other cultivated species. (Hernándo Bermejo and León, 1994). Traditionally in our country pumpkin is mostly used and cultivated when mature for human food, baking including the fruit flesh which together with cereals paste mixes and prepared food called pie. Also, the seeds used in nutrition in various forms, the seeds are eaten whole. These cucurbits are prized for their oilseed, are good sources of lipids and proteins (Achu et al., 2005; Loukou et al., 2007) cited by Koffi et al. (2009). The C. pepo has long been cultivated not only for food but also for their medicinal properties. Particular medicinal properties have been attributed to each part of the fruit and the plant. Pumpkin seed help stimulate appetite, are beneficial for the teeth, nerves, hair and nails. Today, $C$. pepo is among the economically most important vegetable crops worldwide and is grown in almost all temperate and 
120

subtropical regions (Paris, 1996). The traditional land races are the important genetic resources for plant breeders because of their considerable genotypic variations. These variability are maintained by farmer selection for specific traits. Morphological characterization is the first step in the description and classification of genetic resources (Balkaya et al., 2010). Evaluation of the primitive cultivars and their germplasm needs to used to develop new cultivars that are more productive and of greater food value. A wider genetic base of $C$. pepo, thus, assumes priority in plant breeding research aimed at developing new varieties for increased productivity. The objective of this study is to characterize the collection of pumpkin populations from different geographical zones in Kosovo. We analyzed the variability within the $C$. pepo collection were grouped on the basis of morphological characterization include seed lipids (SL) and proteins content (PC).

\section{Material and methods}

\section{Plant material and collection sites}

The field survey was carried out during year 2010 with aim of determining and preserving the characteristics of pumpkin populations (PP). Pumpkin populations (PP) used in this study were collected from different regions in Kosova and variation in morphological and nutritive values include protein and lipids content was assessed. The accession number and geographical distribution of Pumpkin populations was following: 5 populations from Ferizaj, 2 populations from Fushë Kosova, 2 populations from Podujeva, 2 populations from Prishtina and 1 populations from Drenas. In total, 12 populations were investigated (Tab. 1).

The overall climate is a modified continental type, with some elements of a sub-Mediterranean climate in the extreme south. Summers are hot, with extremes of up to 37 degrees. The average annual rainfall is $720 \mathrm{~mm}$. The varied altitude, climatic influences, and soils within Kosovo

Tab.1. Accession of Cucurbita pepo analyzed with their geographical origin

\begin{tabular}{ccccc}
\hline Code & Longitude & Latitude & Elevation & $\begin{array}{c}\text { Geographical } \\
\text { origin }\end{array}$ \\
\hline 'FAPP-01' & $020^{\circ} 56^{\prime} 54^{\prime \prime}$ & $42^{\circ} 50^{\prime} 46^{\prime \prime}$ & 529 & Vushtrri \\
\hline 'FAPP-02' & $021^{\circ} 06^{\prime} 26^{\prime \prime}$ & $42^{\circ} 50^{\prime} 46^{\prime \prime}$ & 545 & Ferizaj \\
'FAPP-03' & $021^{\circ} 13^{\prime} 56^{\prime \prime}$ & $42^{\circ} 20^{\prime} 35^{\prime \prime}$ & 562 & Ferizaj \\
\hline 'FAPP-04' & $021^{\circ} 11^{\prime} 08^{\prime \prime}$ & $42^{\circ} 41^{\prime} 48^{\prime \prime}$ & 621 & Prishtinë \\
'FAPP-05' & $021^{\circ} 07^{\prime} 10^{\prime \prime}$ & $43^{\circ} 00^{\prime} 17^{\prime \prime}$ & 748 & Podujevë \\
\hline 'FAPP-06 & $021^{\circ} 07^{\prime} 10^{\prime \prime}$ & $43^{\circ} 00^{\prime} 17^{\prime \prime}$ & 748 & Podujevë \\
'FAPP-07' & $021^{\circ} 19^{\prime} 75^{\prime \prime}$ & $42^{\circ} 38^{\prime} 57^{\prime \prime}$ & 601 & Drenas \\
\hline 'FAPP-08' & $021^{\circ} 09^{\prime} 70^{\prime \prime}$ & $42^{\circ} 26^{\prime} 46^{\prime \prime}$ & 613 & Ferizaj \\
'FAPP-09' & $021^{\circ} 06^{\prime} 30^{\prime \prime}$ & $42^{\circ} 22^{\prime} 54^{\prime \prime}$ & 610 & Ferizaj \\
\hline 'FAPP-10' & $021^{\circ} 18^{\prime} 74^{\prime \prime}$ & $42^{\circ} 07^{\prime} 90^{\prime \prime}$ & 594 & Fushë Kosovë \\
'FAPP-11' & $021^{\circ} 00^{\prime} 63^{\prime \prime}$ & $42^{\circ} 38^{\prime} 50^{\prime \prime}$ & 587 & Fushë Kosovë \\
\hline 'FAPP-12' & $021^{\circ} 06^{\prime} 30^{\prime \prime}$ & $42^{\circ} 22^{\prime} 54^{\prime \prime}$ & 613 & Ferizaj \\
\hline
\end{tabular}

provide a wide diversity of Pumpkin. C. pepo was grown both in maize fields while the average quantity of fertiliser (NPK) was $300 \mathrm{~kg} / \mathrm{ha}$.

All observations and analyses were carried out in 9 plants from each population. All characters were measured in the field and laboratory at the normal harvest time.

\section{Methods for proteins and lipids extraction}

At harvest time, the pumpkin fruits were taken to the Faculty of Agriculture in Prishtina, which are analyzed for different morpho-biometrical parameters using descriptors, while at department of Chemistry was determined protein and lipids content. The protein content (PC) was determined by the Kjeldahl method, while lipids content (LC) were determined by extraction using Soxhlet apparatus and diethyl ether was used as extraction solvent.

\section{Statistical analyses}

Duncan's multiple range test was used to compare means and significance was accepted at LSD $\mathrm{p}=0.05$ level of probability, to performed for each trait and to identify the variability within populations. Mean values of the agronomic traits for pumpkin populations were standardized and used for computing Euclidean distances between them. Statistical analysis was performed using the statistical program of MINITAB-14, SASS-JMP-IN 5.1.2 (2004) and Excel program.

\section{Results and discussion}

The present collection showed appreciable genotypic variation in morphological and biometric parameters. A fruit characteristic of $C$. pepo is perhaps the most variable species for fruit characteristics in the plant kingdom. In our results fruit shape varied from oval $(\mathrm{O})$ to cylindrical (C). Most populations in this study had oval (50\%), cylindrical (33.33\%) and elliptical fruit (16.16\%). Substantial morphological genetic diversity is given in Tab. 2. Much of the variability in fruit characteristics among cultivated C. pepo can be attributed to the different quality characteristics needed for the culinary use of the mature fruit flesh (Paris, 2010).

The results showed variation among populations for other parameters which are include in our study. The average value of fruit weight (FW) across pumpkin populations was $1733.37 \mathrm{~g}$ per fruit. The average value of $\mathrm{FW}$ at individual populations varied from $1053.43 \mathrm{~g}$ to $3910.33 \mathrm{~g}$ respectively. Results obtained from this they are relevant to identify the genetic variability. The differences for genetic variation between PP for FW were +2856.9 g per fruit or $164.81 \%$ respectively. Our values for FW are different from others. Augustinovic et al. (2006) had obtained on average value $3889 \mathrm{~g}$. In terms of skin thickness (ST) and tail length (TL), there were big differences among the populations. Average populations for ST and TL varied from 4.51 to $0.86 \mathrm{~mm}$ and 11.06 to $4.31 \mathrm{~cm}$ respectively. The 
Tab. 2. Variability of some morphological-biometrical parameters for pumpkin populations

\begin{tabular}{cccccc}
\hline Accessions & $\begin{array}{c}\text { Fruit } \\
\text { shape }\end{array}$ & $\begin{array}{c}\text { Fruit } \\
\text { weight } \\
(\mathrm{g})\end{array}$ & $\begin{array}{c}\text { Flesh } \\
\text { thickness } \\
(\mathrm{cm})\end{array}$ & $\begin{array}{c}\text { Skin } \\
\text { thickness } \\
(\mathrm{mm})\end{array}$ & $\begin{array}{c}\text { Tail } \\
\text { length } \\
(\mathrm{cm})\end{array}$ \\
\hline 'FAPP-01' & $\mathrm{O}$ & $2252.01^{\mathrm{b}}$ & $3.13^{\mathrm{b}}$ & $1.03^{\mathrm{dc}}$ & $5.73^{\mathrm{cdc}}$ \\
\hline 'FAPP-02' & $\mathrm{E}$ & $1216.70^{\mathrm{b}}$ & $2.23^{\mathrm{b}}$ & $0.93^{\mathrm{c}}$ & $4.31^{\mathrm{c}}$ \\
'FAPP-03' & $\mathrm{O}$ & $1053.43^{\mathrm{b}}$ & $2.36^{\mathrm{b}}$ & $2.23^{\mathrm{bcd}}$ & $6.73^{\mathrm{bcdc}}$ \\
\hline 'FAPP-04' & $\mathrm{O}$ & $1056.93^{\mathrm{b}}$ & $1.83^{\mathrm{c}}$ & $0.26^{\mathrm{f}}$ & $11.06^{\mathrm{a}}$ \\
\hline 'FAPP-05' & $\mathrm{O}$ & $1260.56^{\mathrm{b}}$ & $2.63^{\mathrm{b}}$ & $0.86^{\mathrm{c}}$ & $7.83^{\mathrm{bcd}}$ \\
\hline 'FAPP-06 & $\mathrm{C}$ & $1933.83^{\mathrm{b}}$ & $3.03^{\mathrm{b}}$ & $1.16^{\mathrm{dc}}$ & $7.13^{\mathrm{bcdc}}$ \\
\hline 'FAPP-07' & $\mathrm{O}$ & $1736.23^{\mathrm{b}}$ & $3.31^{\mathrm{b}}$ & $0.86^{\mathrm{c}}$ & $9.06^{\mathrm{b}}$ \\
\hline 'FAPP-08' & $\mathrm{C}$ & $1836.50^{\mathrm{b}}$ & $3.32^{\mathrm{b}}$ & $4.51^{\mathrm{a}}$ & $6.93^{\mathrm{bcdc}}$ \\
\hline 'FAPP-09' & $\mathrm{O}$ & $1415.53^{\mathrm{b}}$ & $2.83^{\mathrm{b}}$ & $2.41^{\mathrm{bc}}$ & $8.13^{\mathrm{abcd}}$ \\
\hline 'FAPP-10' & $\mathrm{C}$ & $1653.66^{\mathrm{b}}$ & $2.73^{\mathrm{b}}$ & $1.10^{\mathrm{dc}}$ & $8.66^{\mathrm{bbc}}$ \\
\hline 'FAPP-11' & $\mathrm{C}$ & $3910.33^{\mathrm{a}}$ & $3.46^{\mathrm{a}}$ & $0.86^{\mathrm{c}}$ & $7.26^{\mathrm{bcdc}}$ \\
\hline 'FAPP-12' & $\mathrm{E}$ & $1474.76^{\mathrm{b}}$ & $2.36^{\mathrm{b}}$ & $3.01^{\mathrm{b}}$ & $5.36^{\mathrm{dc}}$ \\
\hline Mean & & 1733.37 & 2.77 & 1.60 & 7.35 \\
\hline LSD p =0.05 & & 692.22 & 0.67 & 1.30 & 2.95 \\
\hline LSD p =0.01 & & 940.88 & 0.92 & 1.76 & 4.01 \\
\hline
\end{tabular}

*the same letters are significantly different

populations showed great differences for those traits. The genetic variation for ST and TL was $181.87 \%$ and $50.57 \%$ respectively. A flesh thickness (FT) measurement ranged among 3.46 to $1.83 \mathrm{~cm}$. Average value of FT was $2.77 \mathrm{~cm}$. Results are given in Tab. 2. The results were obtained in our study demonstrated that substantial differences in qualitative parameters (proteins and lipids) exist in pumpkin populations. The 12 pumpkin populations studied had considerable variation in proteins and lipids. The seed protein content studied range from 9.53 to $19.73 \%$. The average values of proteins level in fruit flesh (FT) and skin fruit (SF) were 1.35 and $8.03 \%$. These values too are lower than the value of seed protein content $(14.59 \%)$ but significantly higher at LSD $\mathrm{p}=0.01$. The protein content of $C$. pepo was also assayed by Logan et al. (1998) to be $18.9 \%$ and by Achu et al. (2005) being 32.03\%.

The pumpkin seed oil (lipids) typically is a highly unsaturated with oil. The variability in the lipid content is very high resulting from a broad genetic diversity. These studies
Tab. 3. Parameters for protein and lipid content at pumpkin populations

\begin{tabular}{|c|c|c|c|c|c|c|}
\hline \multirow[b]{2}{*}{ Accessions } & \multicolumn{3}{|c|}{ Proteins } & \multicolumn{3}{|c|}{ Lipids } \\
\hline & $\begin{array}{c}\text { Seed } \\
\text { proteins }\end{array}$ & $\begin{array}{l}\text { Fruit } \\
\text { flesh }\end{array}$ & $\begin{array}{l}\text { Fruit } \\
\text { skin }\end{array}$ & $\begin{array}{l}\text { Seed } \\
\text { lipids }\end{array}$ & $\begin{array}{l}\text { Fruit } \\
\text { flesh }\end{array}$ & $\begin{array}{l}\text { Fruit } \\
\text { skin }\end{array}$ \\
\hline 'FAPP & $19.26^{\mathrm{ab}}$ & $1.21^{\mathrm{cdc}}$ & $8.26^{\mathrm{abcd}}$ & $37.46^{a}$ & $2.81^{a}$ & $2.06^{a}$ \\
\hline 'FAPP-02' & $18.53^{\mathrm{bc}}$ & $1.26^{\mathrm{cde}}$ & $8.83^{a}$ & $35.71^{\mathrm{b}}$ & $2.81^{\mathrm{a}}$ & $1.86^{\mathrm{abc}}$ \\
\hline 'FAPP-03' & $19.73^{a}$ & $0.93^{\mathrm{c}}$ & $7.96^{\mathrm{cd}}$ & $36.53^{\mathrm{ab}}$ & $2.41^{a}$ & $1.91^{\mathrm{ab}}$ \\
\hline 'FAP & 16 & $1.03^{\mathrm{dc}}$ & $7.91^{\mathrm{cd}}$ & $5.93^{\mathrm{ab}}$ & $2.53^{\mathrm{a}}$ & $2.06^{\mathrm{a}}$ \\
\hline 'FAPP-05 & $18.03^{\mathrm{c}}$ & $0.93^{\mathrm{c}}$ & $8.01^{\mathrm{cd}}$ & $37.16^{\mathrm{ab}}$ & $2.46^{\mathrm{a}}$ & $1.51^{\mathrm{c}}$ \\
\hline 'FAPP-06' & $19.16^{\mathrm{ab}}$ & $92^{\mathrm{c}}$ & $7.73^{d}$ & $37.31^{\mathrm{ab}}$ & $2.36^{a}$ & $1.81^{\mathrm{abc}}$ \\
\hline ‘FAPP-07’ & $10.16^{\mathrm{dc}}$ & $1.66^{\mathrm{b}}$ & $8.13^{\mathrm{bcd}}$ & $23.56^{\mathrm{f}}$ & $1.51^{\mathrm{b}}$ & $1.73^{\mathrm{abc}}$ \\
\hline 'FAPP-08' & $10.51^{\mathrm{de}}$ & $1.46^{\mathrm{bc}}$ & $8.63^{\mathrm{ab}}$ & $30.36^{\mathrm{d}}$ & $1.71^{\mathrm{b}}$ & $1.93^{\mathrm{ab}}$ \\
\hline & $10.66^{\mathrm{d}}$ & $2.23^{a}$ & $8.06^{\mathrm{bcd}}$ & $31.16^{\mathrm{d}}$ & $1.66^{\mathrm{b}}$ & $1.63^{\mathrm{bc}}$ \\
\hline 'FAPP-10' & & $1.36^{\mathrm{bcd}}$ & $6.43^{\mathrm{c}}$ & $26.53^{\mathrm{c}}$ & $1.63^{\mathrm{b}}$ & $1.81^{\mathrm{abc}}$ \\
\hline 'FAPP-11' & $10.56^{\mathrm{d}}$ & $1.73^{b}$ & $8.13^{\mathrm{bcd}}$ & $31.21^{\mathrm{cd}}$ & $1.36^{\mathrm{b}}$ & $1.71^{\mathrm{abc}}$ \\
\hline 'FAPP-12' & $10.91^{\mathrm{d}}$ & $1.51^{\mathrm{bc}}$ & $8.36^{\mathrm{abc}}$ & $33.01^{c}$ & $1.41^{\mathrm{b}}$ & $1.93^{\mathrm{ab}}$ \\
\hline Mean & & & & 32.99 & 2.05 & 1.83 \\
\hline LSD $p=0.05$ & 1.01 & 0.87 & 0.56 & 1.67 & 46 & 0.38 \\
\hline LSD $p=0.01$ & 1.37 & 0.45 & 0.76 & 2.27 & 0.63 & 0.52 \\
\hline
\end{tabular}

*the same letter are significantly different

show that these seeds contain good amounts of oil that can be exploited. Significant variability was observed for the 12 pumpkin populations for seed lipid (SL) were ranged from 37.46 to $23.56 \%$. Overall mean of SL were $32.99 \%$ (Tab. 3). The genetic variation of SL between populations were +13.9 respectively $42.13 \%$, significantly higher at level of probability LSD $\mathrm{p}=0.01$. Yonis et al. (2000) showed that $C$. pepo seeds (CPS) are rich in oil which shows content about $50 \%$. The lipid content in fruit flesh (LCFF) range from 2.81 to $1.41 \%$. The variation of the LCFF content was +1.4 or $68.29 \%$. The lipid content of fruit skin content (LCSC) studied are significantly higher, which ranged from 2.06 to $1.51 \%$. The differences for LCSC between populations were +0.55 or $30.05 \%$. Many authors as Stevenson et al. (2007), who present results for oil content from 37 to $51 \%$. Also the lipid content was also assayed by Achu et al. (2005) which present results from

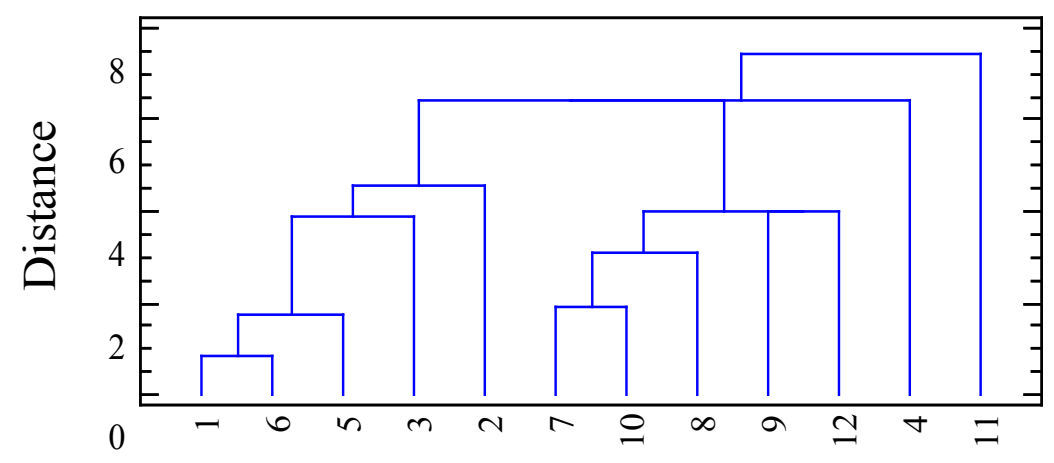

Fig. 1. Genetic grouping of pumpkin populations by cluster analysis 
122

41.90 to $53.85 \%$, and compared with the present results it can be observe a decrease of lipid content.

On the basis of their similarity, the cluster analysis reported the differences between populations. The 12 pumpkin populations were classified into two main groups. The clustering of pumpkin populations on the dendrogram in two separate groups resulted from different morphological and qualitative traits (Fig. 1).

\section{Conclusions}

This study has allowed a better knowledge of the pumpkin populations in different regions of Kosova. Morphological and qualitative characterization showed significant differences between genotypes which exhibited higher protein and lipids content in seed and different parts of fruit. Pumpkin populations were classified into two groups and the number of populations per group varied considerably. These populations are an important source of diversity which could be used in future maybe in different kind processing industry.

\section{References}

Achi M, Fokou E, Tchiegang C, Fotso M, Mbiapo F (2005). Nutritive value of some Cucurbitaceae oil seeds from different regions in Cameroon. African Journal of Biotechnology 4(11):139-1334.

Augustinovic Z, VolfT, Koren M, Martincic M, Dadacek N (2006). Effect of spacing size and shape on oil pumpkin yield (Cucurbita pepo var. oleifera L.). Agriculture 12(2):23-28

Bisognin D (2002). Origin and evaluation of cultivated cucurbits. Ciência Rural 32(5):715-723.

Balkaya A, Ozbakir M, Kurtar E (2010). The phenotypic diversity and fruit characterization of winter squash (Cucurbita maxima) populations from the Black Sea region of Turkey. Afr J Biotech (9)2:152-162.

Francois G, Nathalie B, Pierre V, Daniel P, Didier M (2006). Effect of roasting on tocopherols of gourd seeds (Cucurbita реро). Grasas y aceites 57(4):409-414.

Hernándo Bermejo JE, León J (1994) Neglected Crops: 1492 from a Different Perspective. Plant Production and Protection Series No. 26. FAO, Rome, Italy, p. 63-77.

Koffi K, Anzara G, Malice M, Dje Y, Bertin P, Baudoin J, Bi Z (2009). Morphological and allozyme variation in a collection of Legenaria siceraria (Molina) Standl. from Cote d'ivorie. Biotechnol Agron Soc Environ 13(2):257-270

Logan B, Adams B, Adams III W, Grace S (1998). Antioxidants and xantophyll cycle-dependent energy dissipation in Cucurbita pepo L and Vinca major L. acclimated to four growth PPFDs in the field. J Experim Bot 49(328):1869 1879.

Minitab-14. (2008). www.minitab.com/contacts.

Paris H (2010). Characterization of the Cucurbitapepo collection at the Newe Ya'ar research Center, Israel. PGR Newsletter 126:41-45.

Paris H (1996). Summer squash; history, diversity and distribution. Hort Technol 6:6-13.

SASS-JMP-IN 5.1.2 . (2004). Statistical package programme.

Stevenson D, Eller F, Wang L, Jane J, Wang T, Inglett G (2007). Oil and tocopherol content and composition of pumpkin seed oil in 12 cultivars. J Agric Food Chem 55:4005-4013.

Witaker TW (1947). American origin of the cultivated cucurbits. Ann Missouri Bot Gard 34:101-111.

Yonis YM, Ghirmay S, Al-Shihry (2000). African Cucurbitapepo $\mathrm{L}$, properties of seed and variability in fatty acid composition of seed oil. Phytochemistry 54(1):71-75. 